\title{
Improving Employee Engagement Through Leadership Style
}

By

Scott Beatrice, University of South Florida

$\mathrm{R}$ ecent survey results show almost half of all American workers arrive at their jobs not engaged and only willing to fulfill the minimum requirements - $51 \%$, according to the 2017 Gallup State of the American Workplace survey and 49\% according to 2017 Society for Human Resource Management Employee Satisfaction survey (Gallup, 2017), (Lee, Esen, \& DiNicola, 2017). Additionally, 54\% of employees feel the job "just pays the bills, and 69\% feel recognition is lack ing (www.rewardgate way.com). This lack of engagement appears to have the American workplace in a funk that it is struggling to get out of.

Employee disengagement is demonstrated through lengthy episodes of distraction, slow work tempo, poor decision making, too many days away from work, and a general lack of interest that tends to minimize output (Pech \&e Slade, 2006). Disengaged workers may come to work unmotivated and unwilling to give more than the minimum effort. If managers are not equipped to diagnose and treat this problem, it could be costly. According to Gallup, disengaged workers cost businesses a minimum of $\$ 483$ billion each year (Gallup, 2017).

The purpose of this research was to find a way to reverse this trend by studying the relationships of three critical variables within the workplace:

1. Independent Variable - Psychological Capital (PsyCap) - "an individual's positive psychological state of development and is characterized by: (1) having confidence (self-efficacy) to take on and put in the necessary effort to succeed at challenging tasks; (2) making a positive attribution (optimism) about succeeding now and in the future; (3) persevering toward goals and, when necessary, redirecting paths to goals (hope) in order to succeed; and (4) when beset by problems and adversity, sustaining and bouncing back and even beyond (resilience) to attain success" (Luthans, Youssef, \& Avolio, 2007)

2. Dependent Variable - Employee Engagement, which consists of Meaningfulness - feeling as though one's work makes a difference, Safety - ability to be one's self without fear of consequences, and Availability - having the personal resources to engage at that moment (Kahn, 1990). This was later defined by Schaufeli as a positive work experience consisting of vigor, dedication, and complete work absorption (Schaufeli, Salanova, Gonzalez-roma, \& Bakker, 2002)

3. Moderating Variable - Leadership Style - Transformational Leadership (idealized influence, inspirational motivation, intellectual stimulation, and individualized consideration), Transactional Leadership (contingent rewards and management by exception), and Passive-Avoidant Leadership (laissez faire) (Horwitz et al., 2008)

Keywords: Psychological Capital, Employee Engagement, Transformational Leadership, Trust, Trans actional Leadership, Passive-Âvoidant Leadership, Positive Psychology

Copyright $\odot 2021$ Scott Beatrice. This article is published under a Creative Commons BY-NC license. Permission is granted to copy and distribute this article for non-commercial purposes, in both printed and electronic formats 
This research looked to answer the research question of, "How does Leadership Style moderate the relationship between Psychological Capital (PsyCap) and Employee Engagement?" Within this research question, five hypotheses were presented (Figure 1):

- H1 - Psychological Capital will have a strong, direct, positive relationship to Employee Engagement

- H2 - Transformational Leadership will have a strong, direct, positive relationship to Employee Engagement

- H3 - Transformational Leadership will have the most positive moderating effect on the relationship between Psychological Capital and Employee Engagement

- H4 -Transactional Leadership will have a less positive moderating effect than Transformational Leadership on the relationship between Psychological Capital and Employee Engagement

- H5 - Passive-Avoidant Leadership will have a negative moderating effect on the relationship between Psychological Capital and Employee Engagement

The researcher attempted to find the support for these hypotheses by analyzing quantitative data from surveys collected from 238 workers who were at least 18 years of age and worked more than 20 hours in a week. The survey instrument consisted of the following:

- Psychological Capital Questionnaire - 24 questions measuring individual Psychological Capital (Luthans, Avolio, \& Avey, 2007)

- Multifactor Leadership Questionnaire form $6 \mathrm{~S}-21$ questions measuring Leadership Style (Avolio, Bass, \& Jung, 1999)

- Utrecht Work Engagement Scale (UWES) - 9 questions measuring Employee Engagement (Schaufeli \& Bakker, 2003)

- Basic demographic data - age, sex, and years of experience

\section{Findings}

A two-step process was used to obtain findings. First, descriptive statistics were used to measure overall variables and the different facets within the variables. Second, multivariate correlations were run to measure the strength and direction of the relationships between Psychological Capital, Employee Engagement, and the three Leadership Styles. The findings supported Hypothesis 1, Hypothesis 2, and Hypothesis 3. Hypothesis 4 and Hypothesis 5 were not supported.

A very interesting finding appeared in the statistics evaluating Hypothesis 3. While Transformational Leadership positively moderated the relationship between Psychological Capital and Employee Engagement, the interaction term has a negative coefficient. This means that when Transformational Leadership levels are high, PsyCap has a lesser impact on Employee Engagement, and when Transformational Leadership levels are low, PsyCap has a greater impact on Employee Engagement.

The findings of this research have important implications for practitioners by emphasizing corporate improvement through the promotion of leaders with both high levels of Psychological Capital and the capabilities to lead others in a transformational way. Organizations could use these findings as a starting point to fuel the development of courses and seminars designed to improve PsyCap and Transformation Leadership qualities within its employee base. Practitioners could also work with academics to conduct longitudinal studies and field experiments to measure the effectiveness of the courses and seminars.

Limitations on this study include time constraints and a relatively small sample size. Due to the cross-sectional design of the research, causality could not be determined.

Figure 1: Hypotheses tested

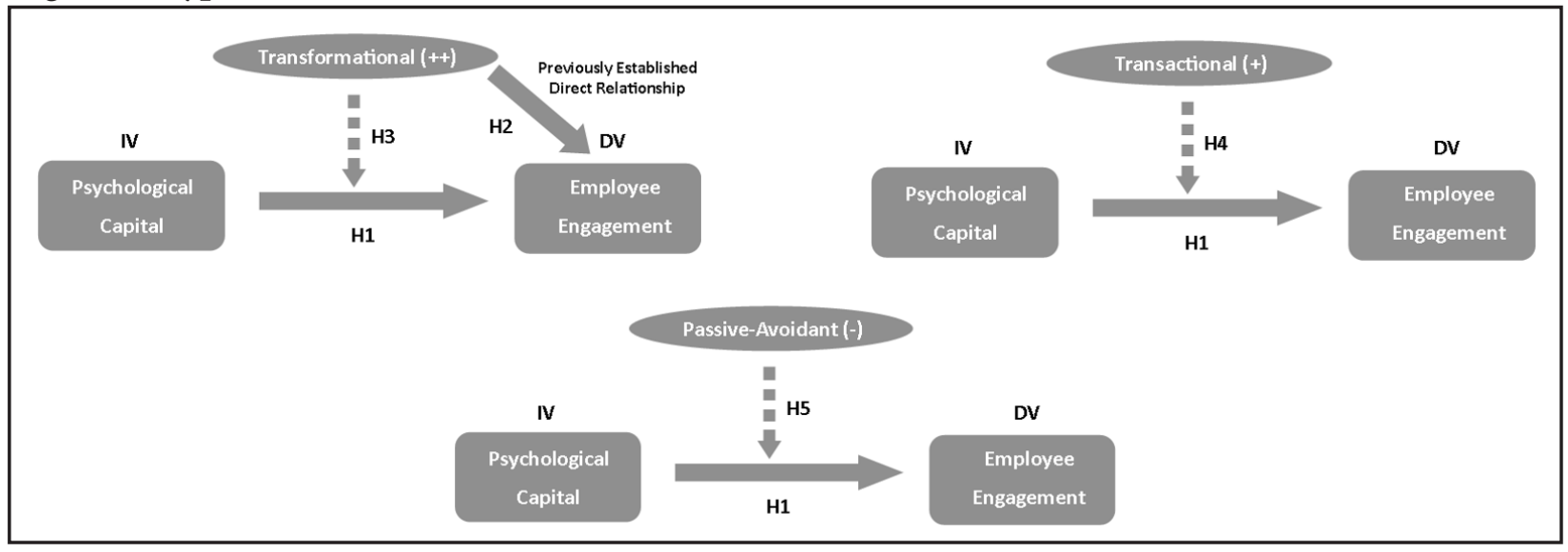




\section{Conclusions}

The results of this research show us that Psychological Capital and Transformational Leadership continue to have a strong, direct impact on the level of Employee Engagement within organizations. The research also demonstrates that Transformational Leadership can positively moderate the effect of the relationship between Psychological Capital and Employee Engagement.

\section{Where to Find Out More}

More information about this research can be found in Improving Engagement: The Moderating Effect of Leadership Style on the Relationship Between Psychological Capital and Employee Engagement (Beatrice, 2019).

\section{References}

Avolio, B. J., Bass, B. M., \& Jung, D. I. (1999). Re-examining the components of transformational and transactional leadership using the Multifactor Leadership Questionnaire. Journal of Occupational \& Organizational Psychology, 72(4), 441462. https://doi.org/10.1348/096317999166789

Gallup. (2017). State of the American workplace. Retrieved from https://www.gallup.com/workplace/238085/state-american-workplace-report-2017.aspx

Horwitz, I. B., Horwitz, S. K., Daram, P., Brandt, M. L., Charles Brunicardi, F., \& Awad, S. S. (2008). Transformational, transactional, and passive-avoidant leadership characteristics of a surgical resident cohort: Analysis using the Multifactor Leadership Questionnaire and implications for improving surgical education curriculums. Jour- nal of Surgical Research, 148(1), 49-59. https://doi. org/10.1016/j.jss.2008.03.007

Kahn, W. A. (1990). Psychological conditions of personal engagement and disengagement at work. Academy of Management Journal, 33(4), 692. https://doi.org/10.5465/256287

Lee, C., Esen, E., \& DiNicola, S. (2017). Employee job satisfaction and engagement: The doors of opportunity are open. Retrieved from www.shrm. org

Luthans, F., Avolio, B. J., \& Avey, J. B. (2007). Psychological Capital (PsyCap) Questionnaire (PCQ). Retrieved from www.mindgarden.com

Luthans, F., Youssef, C. M., \& Avolio, B. J. (2007). Psychological capital : developing the human competitive edge: Oxford University Press.

Pech, R., \& Slade, B. (2006). Employee disengagement: is there evidence of a growing problem? Handbook of Business Strategy, 7(1), 21-25. https:// doi.org/10.1108/10775730610618585

RewardGateway.com. (2017). Employee Recognition: A Missed Connection among People and Bosses. Retrieved from https://www.rewardgateway.com/thank-you-infographic-inside-world-global- employee-recognition

Schaufeli, W. B., \& Bakker, A. B. (2003). Utrecht Work Engagement Scale: Test Manual. Retrieved from www.wilmarschaufeli.nl

Schaufeli, W. B., Salanova, M., González-Romá, V., \& Bakker, A. B. (2002). The measurement of engagement and burnout: A two sample confirmatory factor analytic approach. Journal of Happiness studies, 3(1), 71-92. https://doi. org/10.1023/A:1015630930326.

\section{Author}

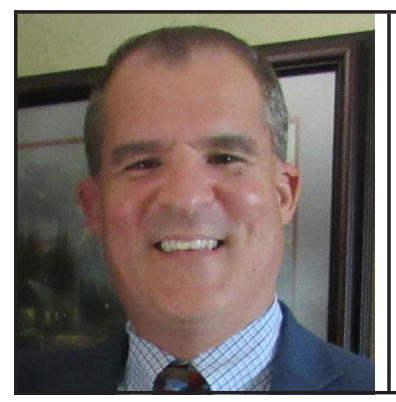

Scott Beatrice is both a Continuing Unit claims examiner with GEICO insurance and an adjunct professor at Florida Southern College. In his capacity as an insurer, he investigates and resolves the most challenging of auto claims. At Florida Southern College, he teaches classes in management and hopes to eventually become a full-time professor. Scott earned his DBA from the Muma College of Business at the University of South Florida in 2020, his MBA with a concentration in management from the University of Tampa, in Tampa, Florida, in 2009, and a bachelor's degree in marketing, finance, and hotel/resort management from Florida Southern College in Lakeland, Florida, in 1998. 